Ch. SULTAN, A. TERRAZA, B. DESCOMPS, R. JEAN , (Intr. by J.BERTRA:ID). INSERM U. 58 and Department of Pediatrics, CHU, Montpellier France.

Androgen receptors in the neo-natal period : evidence for some "physiological" androgen resistance in male infants.

In previous studies, it has been reported that cultured skin fibroblasts have specific receptors which bind dihydrotestostero. ne (DHT) with high affinity and high specificity. Such a receptor has been demonstrated in adult external genitalia, in new born foreskin and in fetal sex skin, but few data are available concerning the early infancy. The present investigation was designed to find out whether the increase in testosterone (T) levels from birth to 3 months in male infants. could be correlated with a variation in sex skin DHT-receptors. Sex skin fibroblasts were raised from $10 \mathrm{male}$ infants aged from 20 to 180 days. Kd and $B_{m a x}$ values were determined in 3 different sub cultures.

No significant variation in androgen receptor concentration could be detected from birth to 6 months. The levels of DHT-receptor was similar to normal values for new born foreskin or adult external genitalia. Thus, the $T$ rise in early infancy do not induce any variation in sex skin androgen receptors and high levels of plasma $T$ and androgen receptors in target cells are not accompagned by clinical signs of hyperandrogenism.

These data suggest that in the neo-natal period androgen receptor levels should not be regulated by $T$. Some degree of androgen resistance can be evocated in male infant.

M.VANDEWEGHE ${ }^{*}$ and G.VAN VLIET* (Intr.by R.Wolter).

84 Endocrinology Department, University Hospital, Ghent and Pediatric Department, University Hospital St.Pierre, Brussels, Belgium.

Oral absorption of DHEA-sulphate and administration to hypopituitary girls.

In 16 subjects ("Addisonian"adults and hypopituitary children before -or without- adrenarche) the plasma levels of DHEA (D) and its sulphate (DS) were measured after administration of DS per os, in a single dose of $30 \mathrm{mg} / \mathrm{m}^{2}$ body surface. DS levels rose from a mean of $0.09 \mu \mathrm{g} / \mathrm{ml}$ at time 0 , to a peak of $2.39 \mu \mathrm{g} / \mathrm{ml}$ after 240 min.; a concomitant $r i s e$ in the mean $D$ concentration from 53 to $300 \mathrm{ng} \%$ was observed. After $6 \mathrm{hrs}$ DS levels showed a slowly progressive decline, whereas for D a "plateau" forming was observed. From these data it appears that nearly $40 \%$ of the $D S$ administered reaches unmetabolized the general circulation whereas the rise of $D$ is mainly due to in vivo hydrolysis of absorbed DS (conversion rate $+0.15 \%$ ).

After administration of a daity dose of $15 \mathrm{mg} / \mathrm{m}^{2}$ body surface to prepubertal hypopituitary girls (in order to realize a pharmacological adrenarche), plasma concentrations of 0.5 to $1.5 \mu \mathrm{g} / \mathrm{ml}$ DS were reached after one week. The very preliminary clinical data available however do not show a clearcut effect upon growth nor upon pubic hair development in these girls.

H. VANELLI " S. BEPNASCOMI, P. VIRDIS " and

85 G. GIOVANIELLI (intr, by G. GIOVAII!ELLI). Dept. of Pediatrics, Univ. of Parme, Italy.

Gonadotropine response to 3 hours LHin: infusion in cryptorchid (C) and normal (N) children.

LHRE was infected $1 . v$. for 3 hours $(0.55 \mu \mathrm{g} / \mathrm{min}$, ) in $12 \mathrm{C}$ and $6 \mathrm{I}$ children. Easal, peak anc $\Delta$ FSI: values were similar in $C$ and $N$. In contrast, LF: peak ( $4.1 \pm$ $0.35 \mathrm{SEH} \mathrm{mIU} / \mathrm{ml})$ and $\Delta(2.5+0.35 \mathrm{mIU} / \mathrm{ml})$ values in $\mathrm{C}$ were lower than those $(11.5 \pm 1.15 ; 9.2 \pm 1.67 \mathrm{mIU} / \mathrm{ml})$ found in $\mathrm{N}(p<0.001)$. The ahove results were compared with those obtained after a sincle bolus injection of LFRH $\left(100 \mu \mathrm{g} / 1.73 \mathrm{~m}^{2}\right)$ in $72 \mathrm{C}$ and $11 \mathrm{~N}$. In $\mathrm{C}$ the $\mathrm{LH}$ peak was lower after infusion than following bolus infection $(p<0.005)$; no difference vas observed in FSI peak. In II the infusion induced LH and FSH peaks n1 sher than after the bolus $(r<0.005)$.

Therefore, LHIRH infusion seems to be a more appropriate test than the single bolus injection for the recognition of LH defect in cryptorchidism.
86 U.Vetter $^{+}$, E.Heinze, E.Kohne ${ }^{+}$, W.M. Teller, E.Kleihauert,

Center of Pediatrics, University of UIm/Donau, F.R.G. METABOLIC DECOMPENSATION AND DURATION OF REMISSION PHASE IN TYPE I DIABETES MELLITUS (D.M.).

The remission in type I D.M. is characterized by low insulin requirement, no glucose excretion and detectable serum C-peptide. The initial hemoglobin $A_{1}$ (BbA, concentration determines the duration of the remission? a higf $\mathrm{HbA}$ is followed by a short and a low $\mathrm{HbA}$-concentration by long remission phase (Vetter et al., Ped.Res. 13, 1190 (1979)). In the present study of 21 newly diagnosed children with type I D.M. the following parameters vere determined: initial $\mathrm{HbA}$-concentration, the time (days of glycosuria), the mean insulfin dosage (U/kg/day) to recompensate the carbohydrate metabolism, and the duration of the remission.

Results: the regression analysis revealed: HbA vs, mean insulin dosage $r=0.92 ; p<0.001 ; \mathrm{HbA}_{1}$ vs, duration $\delta 8$ glycosuria $r=0.63 ; p<0.01$ and $\mathrm{HbA}$ vs. duration of remission $r=-0.84 ;$ $\mathrm{p}<0.001$; mean insulin dosage vs. duration of remission $r=-0.76$; p<0.001.

Conclusion: the initial metabolic derangement of type I D.M. seems to determine the duration of the remission. Early diagnosis and strict treatment may prolong the duration of the remission phase.

\section{READ BY TITLE}

W.BECK- and P.STUBBE; Department of Pedia-

87 trics,University of Göttingen,W.-Germany studles in Danazol (D) treated pubertal Doys with gynecomastia $(G)$.

Diurnal varlations of LH,FSH and PRL, values before and after LHRH/TRH, testosterone $(T)$ and estradiol ( $E_{2}$ ) were determined in 3 pubertal boys with $G(>6 \mathrm{~cm})$ before $(b)$ and after $200 \mathrm{mg} D$ for 90 days. Pubertal development were classified as P4. Results (mean, standard dev1ations): before $30 \mathrm{~min}$ after

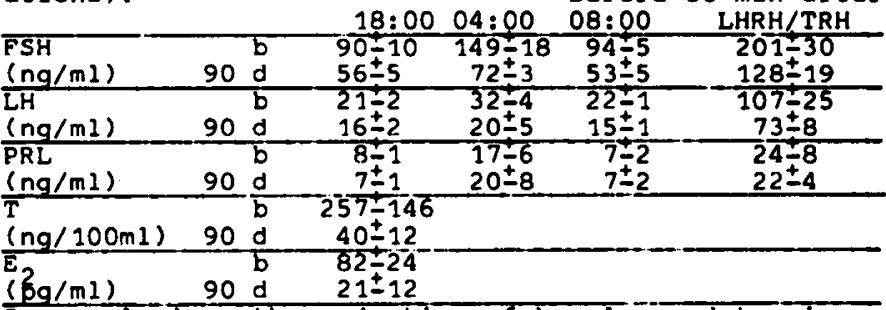
$\frac{(\mathrm{gg} / \mathrm{ml})}{\text { In conclusion: the reduction of basal gonadotropins, }}$ their response to LHRH as well as the reduction of the sleep-related hormone increases suggest that $D$ acts at hypothalamic-pitultary level. The reduction in breast size to $2 \mathrm{~cm}$ in diameter in 2 boys may be due to decreased gonadotropins and lowered $E_{2}$ levels.

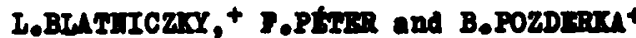
88 Buda Chlldronis Boopltal and Polrolsnic, Budapert. Bungers.

Caman peptide exaninations in chenienl dinbotes The authore tool into conolderation the exteria of obentoel dinbotos cooording to Guthrio. In oase of

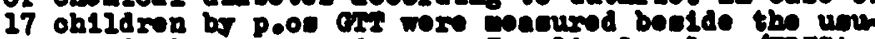

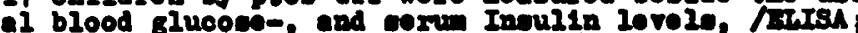

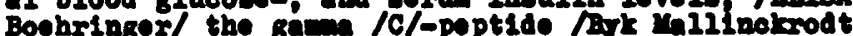
RIA/ velues, too. The roulte of C-poptide topte in

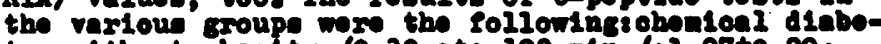

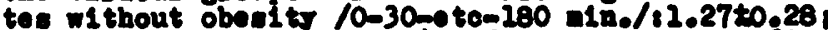
$3.77 \pm 1.2,5.28 \pm 1.84,4.88 \pm 0.96 ; 4.01 \pm 0.97 ; 3.96 \pm 1.1$

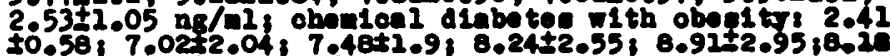

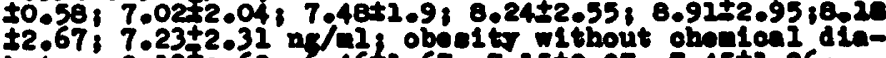
botoes $2.2370 .62,6.46 \pm 1.67$; 7.25t2.07, 7.45+1.96: $6.78+1.38 ; 6.06+2.11 \mathrm{ng} / \mathrm{il}$. If bealdee the want alec the Individuni ourven anniged it oan bo etated that a. /the normileation of blood glueoce ourven ace oording to Cuthrio is ueunils not parmilel with tho normileation of Inoulin and copeptide ourves b.f the ohouloel diebetes without obealty, bowever, is u-

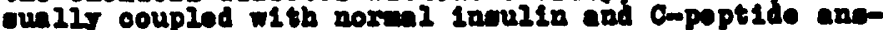
wore acouring the ageunption that othor faotory provole pathologloul slucowe intabolima; 0./1t al00 00oure rarelo that the Ingulin and Copoptide ourver ax not paraliel. 